Ethiopian Journal of Environmental Studies \& Management 9(6): 700 - 712, 2016.

ISSN:1998-0507

Submitted: May 10, 2016

doi: http://dx.doi.org/10.4314/ejesm.v9i6.4

Accepted: November 01, 2016

\title{
HYDROGEOLOGICAL DEEP PERCOLATION MODELLING OF GROUNDWATER RECHARGE IN VOINJAMA REGION, LIBERIA
}

\author{
ONAFESO, 0.D., 1 OLUSOLA, A.0. ${ }^{2}$ AND ADENIYI, S.A.2,3 \\ ${ }^{1}$ Department of Geography, Olabisi Onabanjo University, Ago-Iwoye, Nigeria \\ ${ }^{2}$ Department of Geography, Osun State University, Osogbo, Nigeria \\ ${ }^{3}$ Department of Geography and Environmental Studies, Stellenbosch University, South \\ Africa
}

\begin{abstract}
Indirect physical methods of assess groundwater recharge rely on the measurement or estimation of soil physical parameters, which along with soil physical principles; can be used to estimate the potential or actual recharge. However, the deep percolation method uses a daily water- budget approach to simulate deep percolation. In this method, the model computes daily fluxes of water into and out of a volume extending from the top of foliage to the bottom of the root zone and accounts for changes in water content. In most environments, deep percolation is destined to recharge the saturated systems that are tapped by wells. Deep percolation technique was deployed to determine the rate of ground water recharge in the Voinjama region of Liberia, and also establish points of lineaments where wells can be dug for water supply. The perimeter of the hypothesized basin is about $28.9 \mathrm{~km}$ while the length of the thalweg of the mainstream is about $11 \mathrm{~km}$. the average width of the basin area is $5.9 \mathrm{~km}$ while the circumference of the equivalent circular area is $25.33 \mathrm{~km}$ and compactness coefficient $(R)$ of the basin is computed at 1.14. The elongation ratio $\left(E_{r}\right)$ is computed at $0.73 \mathrm{~km}$. The diurnal recharge computed from Deep Percolation was $6712.21 \mathrm{~cm}^{3} / \mathrm{km}^{2}$ per annum. In conclusion, this study aids the restoration of water supply system destroyed during the war periods emphasizing the abundant water in the hydrological system and viable ground water recharge adequate for exploitation in a near uniform geology. Several faults and crevices scattered abroad the area were recorded indicating good lineament distribution and abundant aquifer recharge.
\end{abstract}

Key Words: Hydrogeology, Deep Percolation Method, Groundwater, Recharge

\section{Introduction}

Liberia, recovering from a 14 year civil war is currently turning from a state of emergency to one of development, as such; much of the population which hitherto has had no access to improved drinking water sources is being targeted for portable water supply. Today, safe water supply depends on boreholes and hand dug wells particularly in the Lofa 
county capital, Voinjama city (26,594 inhabitants), since the communal pipe network got destroyed during the war (Williams, 2002; Herbert, 2014). Whereas, finding water requires appropriate site selection to increase success rates and enhance water point performance based on deeper understanding of the hydrogeological environment, such knowledge is limited, thus leading to high failure rates up to $40 \%$ or higher among groundwater project implementers.

Groundwater recharge, also called deep drainage or deep percolation, is a hydrologic process where water moves downward from surface water to groundwater. This process usually occurs in the vadose zone below plant roots and is often expressed as a flux to the water table surface. Recharge occurs both naturally (through the water cycle) and through anthropogenic processes (i.e., "artificial groundwater recharge"), where rainwater and or reclaimed water is routed to the subsurface.

Groundwater is recharged naturally by rain and to a smaller extent by surface water (rivers and lakes). Recharge may be impeded somewhat by human activities including paving, development, or logging. These activities can result in loss of topsoil resulting in reduced water infiltration, enhanced surface runoff and reduction in recharge. Use of groundwaters, especially for irrigation, may also lower the water tables. Groundwater recharge is an important process for sustainable groundwater management, since the volume-rate abstracted from an aquifer in the long term should be less than or equal to the volume-rate that is recharged. Recharge can help move excess salts that accumulate in the root zone to deeper soil layers, or into the groundwater system. Tree roots increase water saturation into groundwater reducing water runoff (Fisher, 2008).

Groundwater occurrence has been well described by various authors and a well-established conceptual hydrogeological model for groundwater occurrence exists. Aquifers can develop within the weathered overburden and fractured bedrock but groundwater found in the fresh bedrock is negligible (Acworth, 1987; Wright and Burgess, 1992; Chilton and Foster, 1995; Taylor and Howard, 2000; MacDonald et al., 2005). The development of the weathering profile is controlled by chemical degradation of fresh bedrock (Acworth, 1987). Weathering processes depend on presence of water, oxygen and carbon dioxide. Amount of precipitation, groundwater flow (permeability of material and hydraulic gradient) and vegetation cover (hydrolysis reactions) are therefore drivers for the rate of weathering. Evolutionary cycles of weathering and stripping (fluvial and colluvial erosion) over geological time caused heterogeneities in vertical and horizontal extent of the weathering profile (Taylor and Howard, 2000). Deeper fractures within the bedrock are of tectonic origin (Acworth, 1987).

The British Geological Society classification of the weathering profile describes three main lithological sequences that can be further considered as framework of the conceptual hydrogeological model for groundwater occurrence (Wright and Burgess, 1992). Depth to bedrock, thickness of sequences and additional lithological specifications (e.g. soil type) are variable parameters 
depending on local conditions. The base of the saprolite is promising for groundwater development because of less clay minerals and coarser grain size fractions (even rock fragments). Moderate to low yields between 0.1-1 1/s can be expected if an extensive saprolite zone is present (MacDonald et al., 2005). It is questionable if higher borehole yields correlate with thicker water saturated saprolite (Wurzel, 2001). For instance, Wright and Burgess (1992) didn't observe a correlation from analysing 929 borehole $\operatorname{logs}$ in Zimbabwe but Agyekum and DapaahSiakwan (2008) examined 2458 borehole logs in north-eastern Ghana and found a strong tendency of higher yield versus deeper weathering. Many factors of uncertainty like the hydraulic gradient and technical borehole aspects might make analysis difficult. Taylor and Howard (2000) suggest based on pumping test results to target only the regolith extent $(\mathrm{T}=5-20 \mathrm{~m} 2 /$ day $)$, since transmissivities of the saprock ( $\mathrm{T}=$ approximately $1 \mathrm{~m} 2 /$ day) are much lower.

However, MacDonald et al. (2005) recommend targeting the saprock by identifying deeper tectonic fractures is undoubted required for successful siting in areas of poor weathering. Appropriate siting increases drilling success rates and improves borehole yield performance. A wide range of methods are used in Africa from unscientific divining to expensive exploratory drilling (MacDonald et al., 2005). The UNDP guideline for site selection subdivides specific methods in the following categories: geophysical investigations, remote sensing interpretation, hydrogeological fieldwork, and reconnaissance of existing hydrogeological data, local knowledge and exploratory drilling (van Dongen and Woodhouse, 1994). However, all methods are only suited to answer specific questions and a promising prospection strategy should involve an integrated method approach to meet the challenges of siting (MacDonald et al., 2005). This study attempts an analysis of the hydrogeological recharge capacity of the Voinjama region by employing the deep percolation method.

\section{Study Area}

The Voinjama region in Liberia is an extremely rugged hilly topography with rounded and elongated tops up to $300 \mathrm{~m}$ above the surrounding terrain and dense rainforest except when cleared characterize the landscape of Voinjama city, like most of the Lofa county (Seitz, 1974). The average terrain of the area lies on approximately $400 \mathrm{~m}$ above sea level and only the Wologizi mountain range to the west of Voinjama city, rises up to $1400 \mathrm{~m}$. Annual precipitation ranges between 2000-3000mm, much less than at the $5000 \mathrm{~mm}$ along the coastline of Liberia (De Boer et al., 1982). Still, rainfall is high compared to most other areas of sub-Saharan Africa (MacDonald et al., 2005). The rainy season lasts from May to October with peak values in July and August. A period from December to April is the driest and it is important to notice that a mid-dry phenomenon is absent. The temperature remains relatively stable around $26^{\circ} \mathrm{C}$ throughout the year with extreme values between 10 $37^{\circ} \mathrm{C}$ (Reed, 1951). 


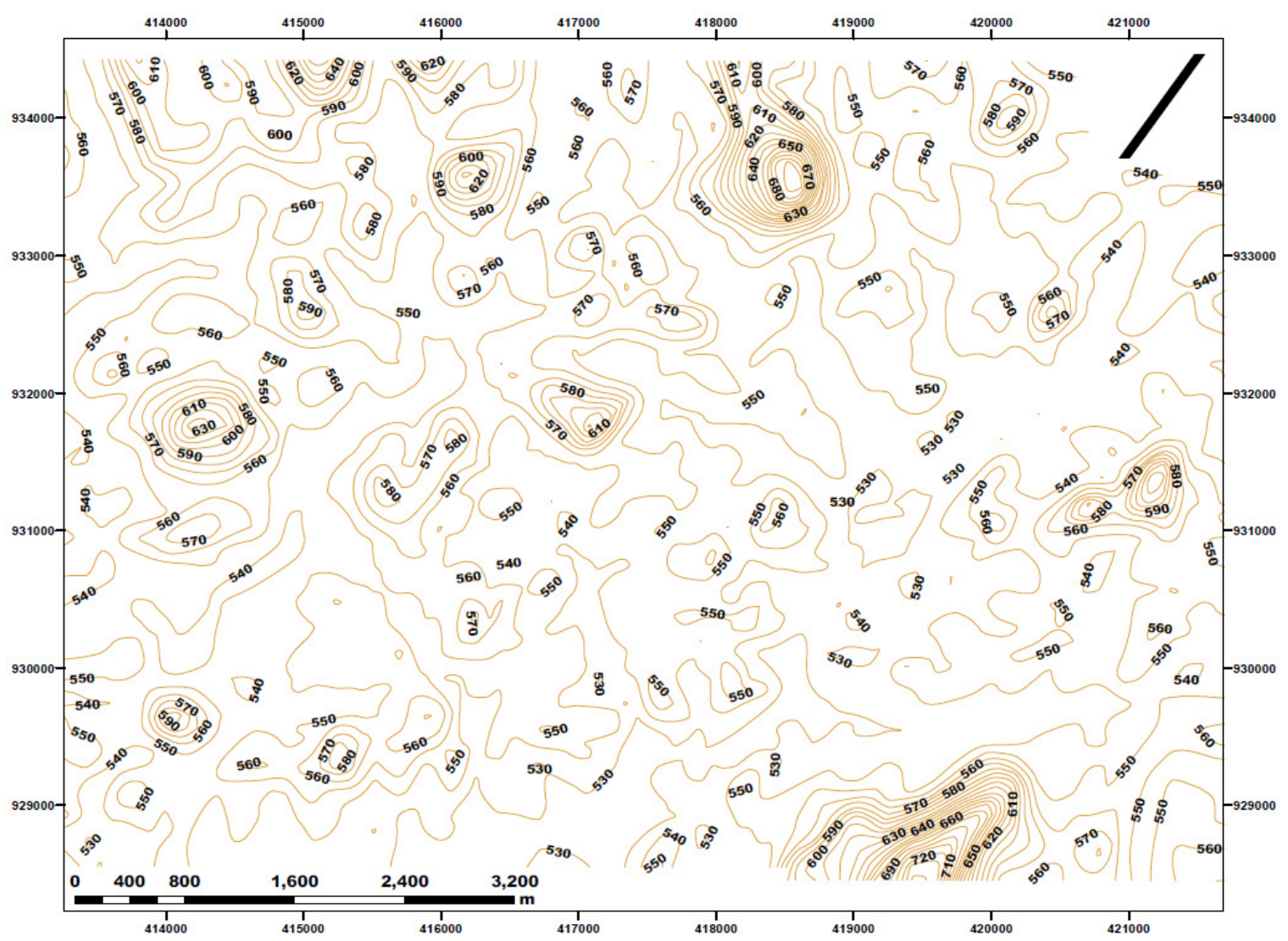

Figure 1 Topographic map of the Voinjama city generated from SRTM

The area is part of the West African Craton (Leo or Man terrane) and crystalline rocks are dominant unlike at the coastline where unconsolidated sediments are found (Schlüter, 2008). Voinjama city lies upon the Precambrian Guinean Shield (Seitz, 1974). Granitic gneiss and granite (gradual transition) make up $85 \%$ of the dominant rock types besides ultramafic rocks, amphibolite, dolerite dikes, schists and iron formations (Beherent and Wotorson, 1974). Intensive weathering of rocks causes outcrops of bedrocks only to be exposed at road cuts, stream channels and rounded Inselbergs (granitic domes) with steep flanks (Seitz, 1974). Thermotectonic activity taking place 2.7 billion years ago (Liberian Age Province) was responsible for major folding, faulting and shearing with a general structural north east trend (White, 1970). Dolerite dikes are estimated to be 1.2-2.8 billion years old in the entire Lofa region. That is much older than in other parts of Liberia where Jurassic Age was determined with radioactivity methods (Grommé and Dalrymple, 1972).

Lateritic soil is usually the top sequence of the weathering profile (Reed, 1951). Approximately $40 \%$ of sub-Saharan Africa is underlain by Precambrian crystalline bedrock (MacDonald et al., 2005). 


\section{Method}

The primary method adopted for estimating ground-water recharge from precipitation for this study is the near surface water-balance method, a deeppercolation model (DPM), developed for eastern Washington (Bauer and Vaccaro, 1987) and modified for western Washington (Bauer and Mastin, 1997), was selected to estimate deep percolation from precipitation for this study. The DPM uses a daily water- budget approach to simulate deep percolation. In this method, the model computes daily fluxes of water into and out of a volume extending from the top of foliage to the bottom of the root zone and accounts for changes in water content.

Time-series data required for this application of the DPM include daily values of precipitation, precipitation throughfall, minimum and maximum air temperature, solar shortwave radiation, and "direct runoff." Direct runoff is herein defined as surface-water runoff plus water that drains from temporarily saturated soils to local drainage features. Spatial data required for the DPM include land-surface altitude, properties of soils, and land cover (vegetation type, surface water, or impervious surfaces). Areal variation in soils, vegetation, and land cover is accounted for in the DPM by dividing a drainage area into cells or polygons of any size and shape. Each cell is characterized by a single altitude (and optionally, surface slope and aspect), land cover, soil type, subsoil infiltration capacity, and climate regime. Areal variation in precipitation, air temperature, and solar shortwave radiation are accounted for by interpolation of data to each cell from data collected in or near the study basins.
Evapotranspiration depletes soil moisture and depends on soil-moisture content and meteorological conditions. Therefore, evapotranspiration and soil moisture must be calculated at sufficiently frequent intervals to accurately simulate changes. The DPM uses a daily time step, primarily because daily meteorological data generally are available. A daily time step is sufficiently short to ensure that soil moisture variations are small enough to avoid significant error in the evapotranspiration calculations. For each day of a DPM simulation, deep percolation for each cell is computed as the residual of precipitation minus evapotranspiration minus direct runoff minus the change in soil moisture in the root zone.

Direct runoff for each cell is difficult to determine. Although the total direct runoff for the drainage basin can be readily estimated from streamflow measurements, the contributions from individual cells in the basin can vary greatly, depending on the soil and subsoil properties. For example, during a storm, a cell with a thick soil underlain by a permeable sand-and-gravel glacial outwash deposit may not contribute direct runoff, whereas a cell with thin soil overlying poorly permeable glacial till will contribute a large quantity of direct runoff. The DPM disaggregates the daily total measured direct runoff to the cells in proportion to a simulated daily direct runoff for each cell (for details, see Bauer and Mastin, 1997). A specified infiltration capacity beneath the root zone for each cell, based on the soil and subsoil properties, is incorporated into these calculations. By adjusting this parameter, a water balance (or calibration) is achieved. If the infiltration 
capacities are set mostly too large, too little water will be available to support the measured total direct runoff. This is indicated as a "negative deficit" in the DPM output; conversely, a "positive deficit" results when the infiltration capacities are mostly set too small.

Three steps were used to estimate recharge for the area at basin scale using the DPM in this study: (1) the spatial data needed for applying the DPM to the entire study area were assembled, checked for accuracy, and divided into uniform cells; (2) the DPM was calibrated for the study basin; and (3) the
DPM was applied to the entire basin using surface meteorological data collected from the NASA Goddard Earth Observing System satellite.

In step 3, island-wide direct runoff data were not available. The DPM was, therefore, operated in a mode in which the simulated direct runoff for each cell is used in place of the disaggregated measured runoff.

DPM includes both energy and waterbudget components that are represented as physical processes. The process components are represented in the following mass-balance equation:

$\mathrm{R}=\mathrm{P}-\mathrm{SE}-\mathrm{PT}-\mathrm{SRO}-\mathrm{EI}-( \pm \mathrm{SM} \pm \mathrm{IS}) \pm \mathrm{DS}$

where

$R \quad$ is recharge (deep percolation),

$P \quad$ is precipitation,

$S E \quad$ is soil evaporation,

$P T$ is plant transpiration,

$S R O$ is surface runoff,

EI is evaporation of intercepted water,

$\pm S M \quad$ is change in soil water in the root or soil zone,

$\pm I S \quad$ is change in intercepted moisture storage, and

$\pm D S \quad$ is deficit or surplus.

The sum of $S E, P T$, and $E I$ in the equation is the model calculated actual evapotranspiration (AET). The calculated deficit/surplus term $(D S)$ in the equation accounts for direct surface runoff, if input, that the surplus water (water in excess of field capacity) cannot account for or is over accounted for. Either case indicates that:

1) the daily estimates of baseflow made by a user may be either too large or small (even after user adjustments),

2) hydrologic phenomena, such as macropore flow, that are not included in the model can be locally important, or
3) there may be errors in either the soil information or the interpolated weather data. Although deficit/surplus is considered a separate term in DPM's output that is not part of the error term, it reflects an error due to one or more of the above three factors.

\section{Result and Discussion}

Only one perennial stream was identified within the boundaries surrounding Voinjama city as specified for this study $(8.452 \mathrm{~N},-9.789 \mathrm{~W}$ and 8.399 ) about $51.08 \mathrm{~km}^{2}$. The stream which flows south-westward takes its 
source from around the base of the neighboring Guinean highlands to the north of Voinjama, and discharges into the Gbeya River further south-westwards. Only about $11 \mathrm{~km}$ of the nearly $120 \mathrm{~km}$ entire stretch is bounded in the area of study, hence of significance to the water condition of Voinjama city. In all, about ten (10) different flow systems (referred to as sub basins in this report) were encountered within the study area, although it is certain that such flows occur year round.

The area of the basin is estimated as $51.08 \mathrm{~km}^{2}$ since the boundary of the study was has been specified as such. Even though the entire basin covering
Voinjama City is much larger, the boundary area specified for this study covers the entire City and its outskirts. Thus, this hydrological analysis is based on the urban area assessed. The perimeter of the hypothesized basin is about $28.9 \mathrm{~km}$ while the length of the thalweg of the mainstream is about $11 \mathrm{~km}$. the average width of the basin area is $5.9 \mathrm{~km}$ while the circumference of the equivalent circular area is $25.33 \mathrm{~km}$ and compactness coefficient $(\mathrm{R})$ of the basin is computed at 1.14. The elongation ratio $\left(\mathrm{E}_{\mathrm{r}}\right)$ is computed at $0.73 \mathrm{~km}$. The remaining estimated basin characteristics are presented in Table 1.

Table 1: Voinjama Basin Characteristics

\begin{tabular}{lllll}
\hline & $\begin{array}{l}\text { Length of } \\
\text { water course } \\
(\mathrm{m})\end{array}$ & $\begin{array}{l}\text { Average } \\
\text { channel width } \\
(\mathrm{m})\end{array}$ & $\begin{array}{l}\text { Average bankfull } \\
\text { channel depth } \\
(\mathrm{m})\end{array}$ & $\begin{array}{l}\text { Estimated bankfull } \\
\text { volume } \\
\left(\mathrm{m}^{3}\right)\end{array}$ \\
\hline Perennial Stream & 11000 & 10 & 3.5 & 385000 \\
Sub-Watershed 1 & 2900 & 7.2 & 3.1 & 64728 \\
Sub-Watershed 2 & 4600 & 5.1 & 2.8 & 65688 \\
Sub-Watershed 3 & 8300 & 6.2 & 2.5 & 128650 \\
Sub-Watershed 4 & 2150 & 4.4 & 1.8 & 17028 \\
Sub-Watershed 5 & 700 & 3.3 & 1.2 & 2772 \\
Sub-Watershed 6 & 400 & 3.1 & 1.1 & 1364 \\
Sub-Watershed 7 & 3500 & 4.9 & 1.3 & 22295 \\
Sub-Watershed 8 & 3020 & 4.6 & 1.5 & 20838 \\
Sub-Watershed 9 & 800 & 3.2 & 0.8 & 2048 \\
Sub-Watershed 10 & 200 & 2.8 & 0.6 & 336 \\
\hline
\end{tabular}


Hydrogeological Deep Percolation Modelling of Groundwater Recharge.................NAFESO et al.

Table 2: Monthly Basin scale water balance parameters

\begin{tabular}{|c|c|c|c|c|c|c|c|}
\hline & $\begin{array}{l}\text { Basin scale } \\
\text { precipitation } \\
\left(\mathrm{cm} / \mathrm{km}^{2}\right)\end{array}$ & $\begin{array}{l}\text { Estimated } \\
\text { soil } \\
\text { evaporation } \\
\left(\mathrm{cm} / \mathrm{km}^{2}\right)\end{array}$ & $\begin{array}{l}\text { Estimated } \\
\text { plant } \\
\text { transpiration } \\
\left(\mathrm{cm} / \mathrm{km}^{2}\right)\end{array}$ & $\begin{array}{l}\text { Basin } \\
\text { scale total } \\
\text { surface } \\
\text { runoff } \\
\left(\mathrm{cm} 3 / \mathrm{km}^{2}\right)\end{array}$ & $\begin{array}{l}\text { Evaporation } \\
\text { of } \\
\text { intercepted } \\
\text { water } \\
\left(\mathrm{cm} / \mathrm{km}^{2}\right)\end{array}$ & $\begin{array}{l}\text { Change in } \\
\text { soil water } \\
\text { in the root } \\
\text { or soil } \\
\text { zone } \\
\left(\mathrm{cm} / \mathrm{km}^{2}\right)\end{array}$ & $\begin{array}{l}\text { Change in } \\
\text { intercepted } \\
\text { moisture } \\
\text { storage } \\
\left(\mathrm{cm} / \mathrm{km}^{2}\right)\end{array}$ \\
\hline January & 14.3024 & 0.530881 & 0.4256 & 409 & 2.66 & 0.16 & 0.010384 \\
\hline February & 33.202 & 0.562694 & 0.5083 & 950 & 2.99 & 0.17 & 0.012517 \\
\hline March & 78.6632 & 0.63403 & 0.6534 & 2251 & 3.63 & 0.18 & 0.015151 \\
\hline April & 185.9312 & 0.709186 & 0.7486 & 5320 & 3.94 & 0.19 & 0.016459 \\
\hline May & 275.3212 & 0.81312 & 0.8736 & 7878 & 4.16 & 0.21 & 0.016877 \\
\hline June & 421.41 & 0.927699 & 1.012 & 12058 & 4.4 & 0.23 & 0.016584 \\
\hline July & 422.9424 & 1.010749 & 1.0824 & 12102 & 4.51 & 0.24 & 0.015932 \\
\hline August & 546.556 & 1.021867 & 1.1184 & 15639 & 4.66 & 0.24 & 0.015948 \\
\hline September & 486.2816 & 0.948627 & 1.0534 & 13914 & 4.58 & 0.23 & 0.016279 \\
\hline October & 314.142 & 0.846151 & 0.8778 & 8989 & 4.18 & 0.21 & 0.016119 \\
\hline November & 114.93 & 0.784167 & 0.722 & 3289 & 3.61 & 0.2 & 0.015311 \\
\hline $\begin{array}{l}\text { December } \\
\text { Annual }\end{array}$ & 20.9428 & 0.648 & 0.5112 & 599 & 2.84 & 0.18 & 0.011941 \\
\hline Average & 242.8854 & 0.786431 & 0.798892 & 6950 & 3.846667 & 0.203333 & 0.014959 \\
\hline
\end{tabular}

The water balance of the basin as computed using the deep percolation model shows that the amount of rainfall input to the basin is barely sufficient given the daily mean annual average of $4.78 \mathrm{~mm}$ per day. Evaporation was assessed as a total column precipitable water of $3.85 \mathrm{~cm}$ mean annual average while the vegetation of the area was estimated as $18 \mathrm{~m}$ broad leaf savanna with about $30 \%$ ground cover. The basin scale water balance parameters are summarized in the table 2.

The groundwater recharge of the area holding geology and soil condition constant as described above, for the entire Voinjama City is modeled at diurnal scale considering total amounts of water in the hydrological cycle within the closed boundary of Voinjama City is presented in Table 3.
Table 3: Monthly Diurnal Recharge computed from Deep Percolation $\mathrm{cm}^{3}$ $/ \mathrm{km}^{2}$

\begin{tabular}{ll}
\hline & $\begin{array}{l}\text { Diurnal Recharge computed } \\
\text { from Deep Percolation } \mathrm{cm}^{3} \\
/ \mathrm{km}^{2}\end{array}$ \\
\hline January & 398.39 \\
February & 920.71 \\
March & 2176.92 \\
April & 5139.47 \\
May & 7608.30 \\
June & 11642.85 \\
July & 11685.42 \\
August & 15099.06 \\
September & 13434.44 \\
October & 8680.35 \\
November & 3178.56 \\
December & 582.12 \\
Annual & \\
Average & 6712.21 \\
\hline
\end{tabular}

The diurnal recharge computed from deep percolation method gives the above values for the estimate of the basin area, 
as such for every square kilometer and for a given day in the particular month of assessment, the modeled value is recommended. However, further assessment based on actual field study can be taken to validate the models.

The rainfall pattern in most of the sub-Saharan region of Africa is highly variable, especially the Sahel zone where increased desiccation has resulted in recent times due to the intense nature of rainfall variability. The same is the case with Voinjama city and most of Liberia, particularly the northern half with its proximity to the Guinea highlands. The long term (1983 - 2012) rainfall condition is summarized in the figure 2 .

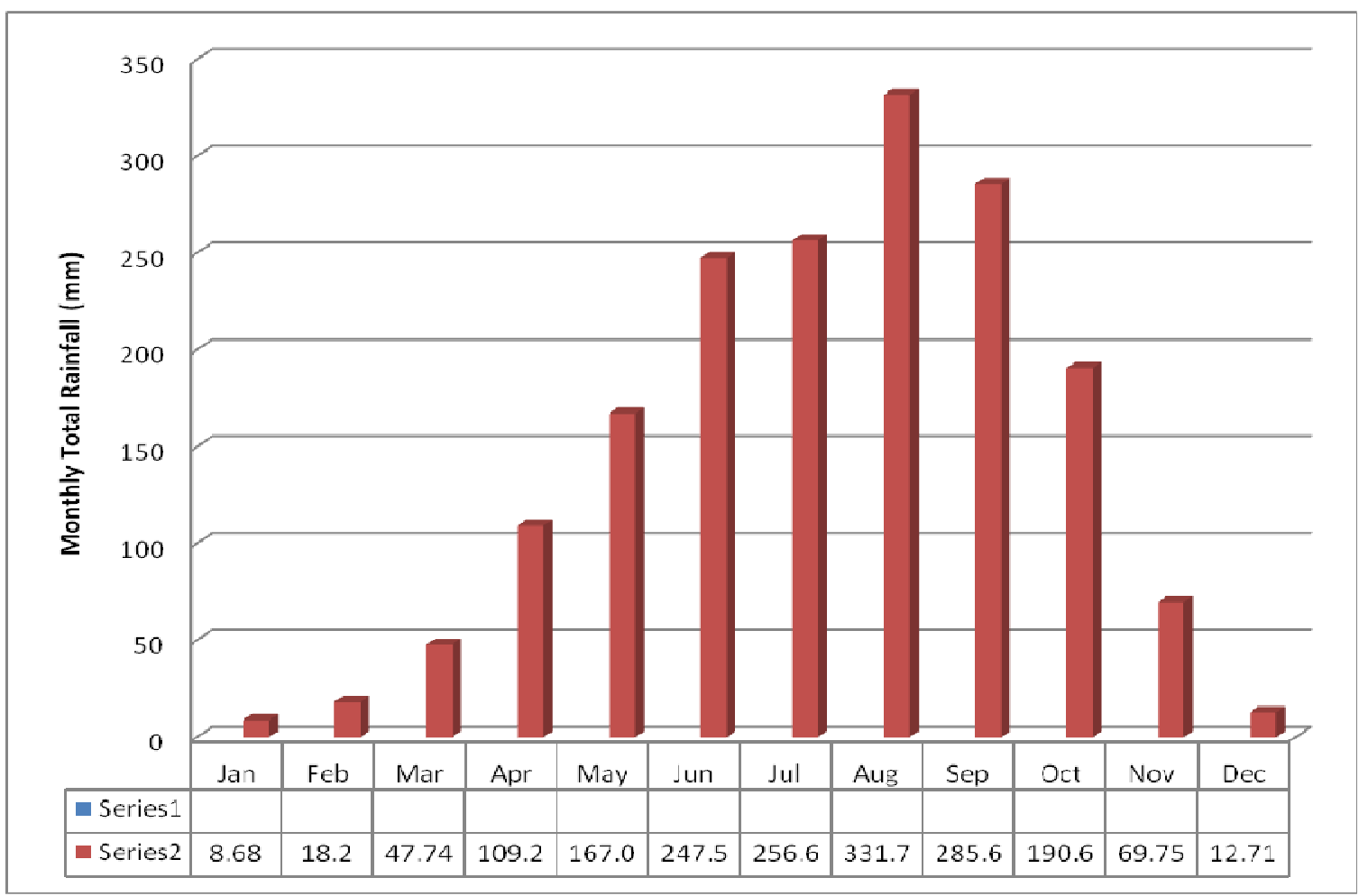

Figure 2: Monthly Rainfall in Voinjama Region

Based on the rainfall summary, Voinjama City experiences rainfall all year round. Although the rainfall pattern varies significantly from year to year, the dry months are mostly dry (December to February). On the average, the onset of rains begins in March when the total rainfall experienced is nearly $50 \mathrm{~mm}$, while the retreat is usually around November with a mean total rainfall of about $70 \mathrm{~mm}$. The highest rainfall is usually experienced in August when total amounts of rain exceeds $300 \mathrm{~mm}$ as shown in the above figure. The rainfall pattern shows a significant single peak rising from about $110 \mathrm{~mm}$ of rain in April and declining to about the same amounts between October and November. As such bankfull condition usually occurs in September after the great floods resulting 
usually from the thunderstorms in August. For most of the year, the perennial water courses are bound to have water, although some of the runoff paths most of which flow through the populated areas of Voinjama city, which have resulted from faults, joints and topographic crevices have water episodes regulated by rain amounts.

The rainfall variability in Voinjama city shows a trend averaging about $2654 \mathrm{~mm}$ per annum. Quite significantly, the rainfall has barely dropped below $2000 \mathrm{~mm}$ since 1983 as shown in the figure 3 .

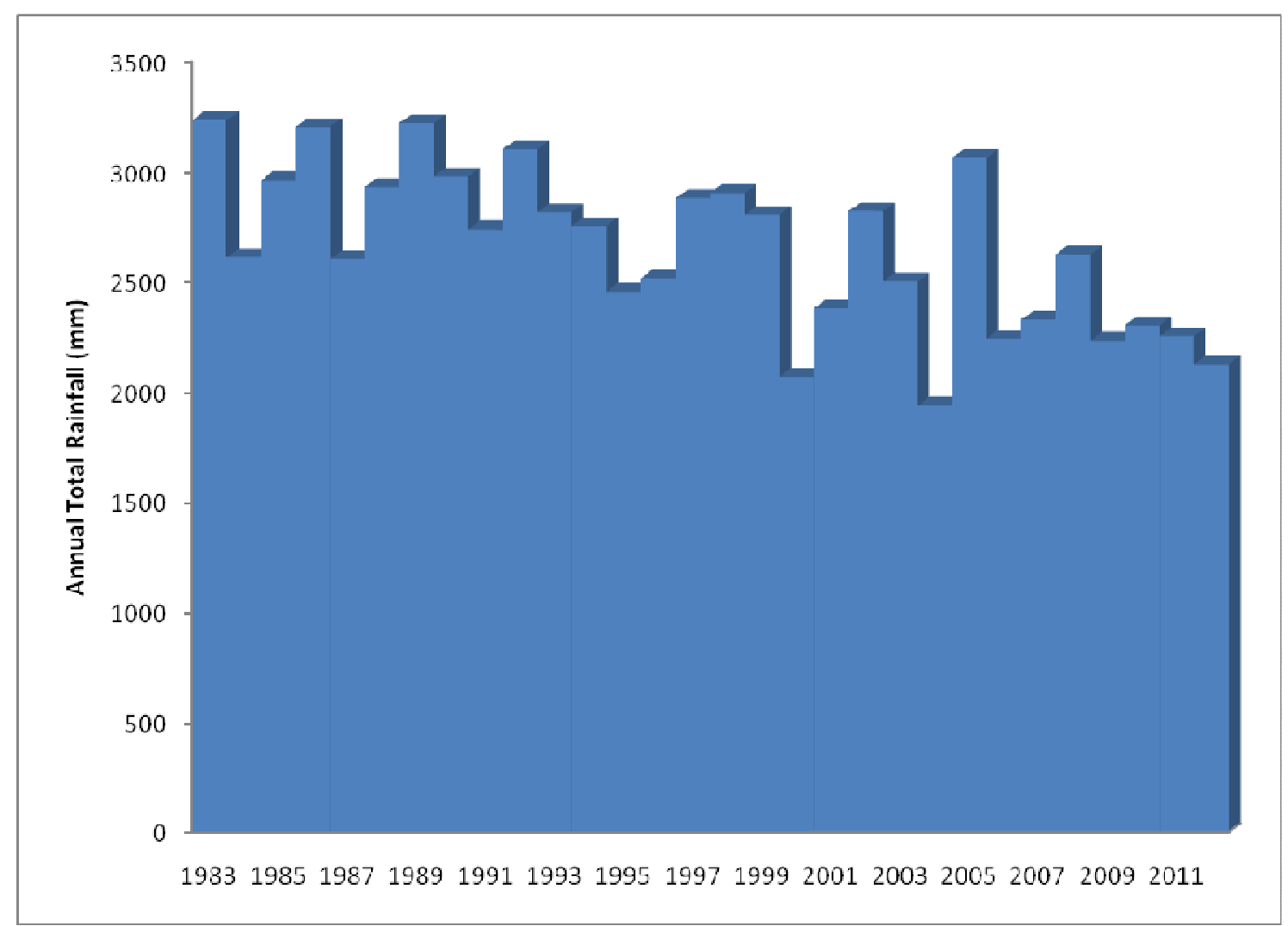

Figure 3: Annual Total Rainfall Amounts in the Voinjama Region

However, over the space of 30 years, the pattern of rainfall over Voinjama City is one of a declining trend. The highest annual total rainfall amount experienced is about 3200mm (1983, 1985, 1989, 1992,), while the lowest annual total rainfall experienced is about $1800 \mathrm{~mm}$ (2004). Before the turn of the century the pattern of rainfall has been fairly consistent without no year experiencing not less than $2400 \mathrm{~mm}$ amount to total annual rainfall (1983-1999). Immediately after the turn of the century, the annual total amount of rainfall declined and experienced the lowest record ever in 2004 (1800m), while its maximum annual total is about $3100 \mathrm{~mm}$ in 2005 . The reason for this could be tied to changing climates and this has significant impact on the total water available within the City. 


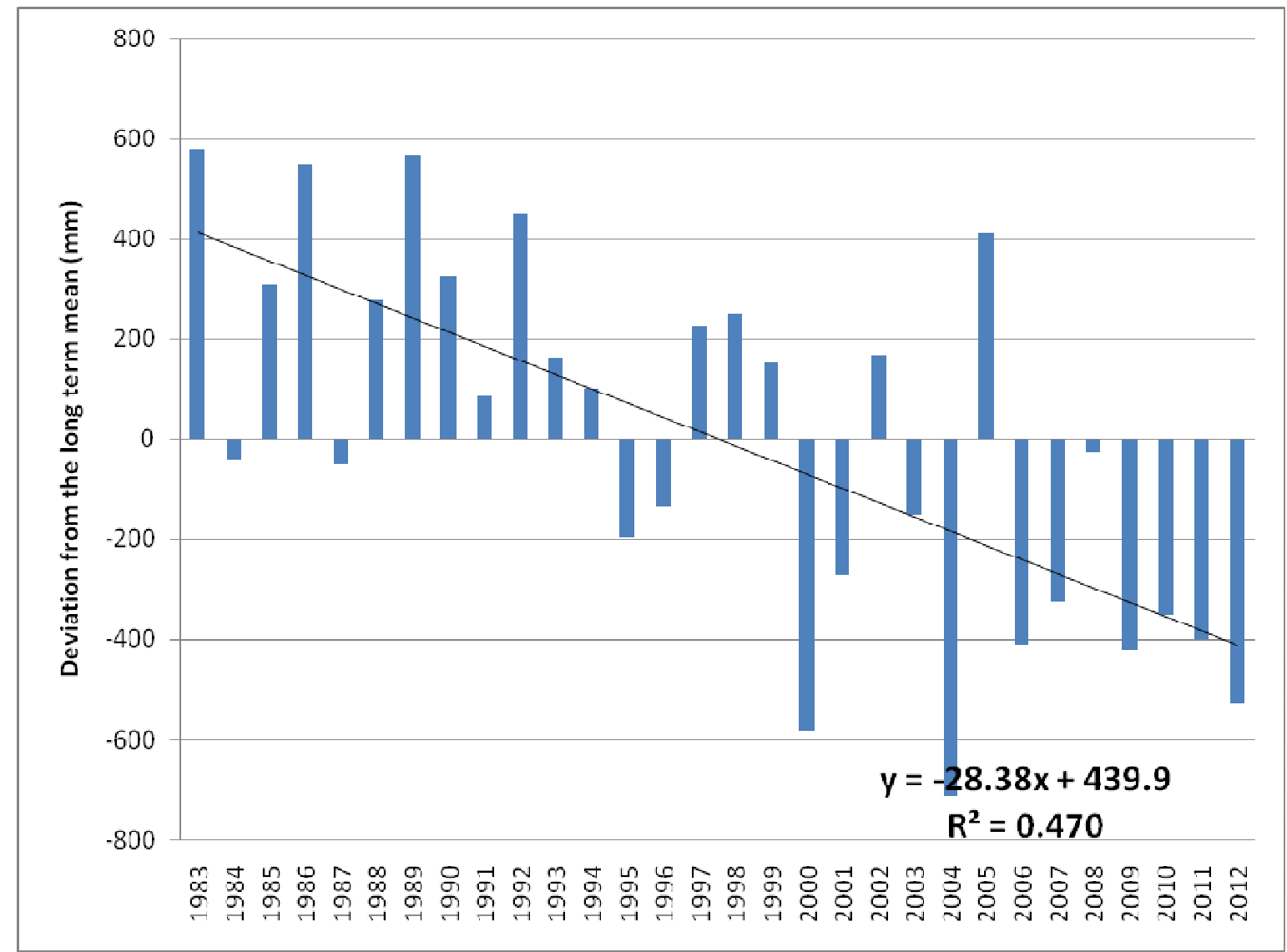

Figure 4: Annual Rainfall Deviations from the long term mean in the Voinjama Region

In tandem with the discussion above, the deviation from the long term mean over the past 30 years shows significant decline after the turn of the century by recording the highest number of years (11 years) having rainfall amount lower than the observed mean over the time period with a deviation of about $700 \mathrm{~mm}$ in 2004 while only two years had rainfall amount greater than the observed 30-year average. Before the turn of the century, only four years experienced rainfall amounts less than the 30-year average with the highest deviation in 1995 (200mm).

To this end, the trend line shows a weak relationship between rainfall amount and the mean average, suggesting that the 30-year average cannot be taken as an approximate of the rainfall amount in a year within Voinjama City, hence implying that each year is unique in its rainfall amount observed and the pattern varies significantly.

Conversely, the regression equation y $=-28.38 x+439.9$ is indicative of the increasing decline of water input from precipitation to feed the recharge of the hydrological cycle. A deficit of about $28.38 \mathrm{~mm}$ rainfall is consistently experienced on an annual basis indicating a dangerous trend towards increasing water shortage. Should the trend continue the implication for water resources and ground water recharge in the region may be that of severe drought which may not 
be found interesting. Although, the $\mathrm{R}^{2}$ value of 0.47 indicates that the rate of declining water availability may leave some time for respite, which may require increased ground water exploitation.

\section{Conclusion}

Although, the rainfall trend in the Voinjama city tells a story of decline, the past water years indicates significant amounts of water input from rainfall in the region. Interestingly, Liberia has received quite a humongous input of water over the years, especially, relative to most of the neighboring countries. This blessing is to the effect that the water supply system destroyed during the war periods may not pose too much problem for redemption in the post war rebuilding process. With abundant water in the hydrological system, stored over the years, it is positive that the ground water recharge is adequate and exploitation may not be limited.

Also, the near uniform geology of the vast region underlain by Pre-Cambrian undifferentiated rocks which is overlain with ferrasols, strongly weathered soils of the humid tropics, though bearing generally low fertility, is a plausible prospect for easy access to water. Moreover, many faults and crevices occur scattered abroad the area indicating good lineament distribution and abundant aquifer recharge. However, field study is requisite to consider the details of the water bearing capacities of the aquifers and the ease of exploitation for water use for the population. Furthermore, the declining trend in precipitation input to the area may be examined with climate change projections to determine exact sustainable water management strategies for Voinjama city.

\section{References}

Acworth, R.I. (1987). The development of crystalline aquifers in a tropical environment. Quarterly Journal of Engineering Geology, 20: 265-272.

Agyekum, W.A. and Dapaah-Siakwan, S. (2008). The occurrence of groundwater in northeastern Ghana. Cited In: Applied groundwater studies in Africa, edited by Adelana, M.A., MacDonald, A.M., Abiye, T.A. and Tindimugaya, C. Taylor and Francis group, London, p.215-231.

Bauer, H.H., and Mastin, M.C. (1997). Recharge from precipitation in three small glacial-till mantled catchments in the Puget Sound Lowland, Washington: U.S. Geological Survey WaterResources Investigations Report 964219, 119 p.

Bauer, H.H., and Vaccaro, J.J. (1987). Documentation of a deep percolation model for estimating ground-water recharge: U.S. Geological Survey Open-File Report 86-536, 180 p.

Beherent, J.C. and Wotorson, C.S. (1974). Geophysical Surveys of Liberia with tectonic and geological interpretations, U. S. Geological Survey, Washington.

Chilton, P.J. and Foster, S.S.D. (1995). Hydrogeological investigation and water-supply potential of basement aquifers in tropical Africa. Hydrogeology Journal, 3(1): 36-49.

De Boer, E., Glay, E. and Hall, C. Jr. (1982). Preliminary study for the water supply of Kolba city (Kolahun), Lofa County, Monrovia.

Fisher, M. (2008) Urban Trees Enhance Water Infiltration. The American 
Society of Agronomy. November 17, 2008. Retrieved from www.agronomy.org on December $10,2015$.

Grommé, S., and Dalrymple, G.B. (1972). K-Ar ages and paleomagnetism of dikes in Liberia. American Geophysical Union, 53 (10), p. 1130. Cited in Seitz, J. F. (1974). Geology of the Voinjama Quadrangle, Liberia, U.S. Geological Survey.

Herbert, S. (2014). Conflict analysis of Liberia.Birmingham, UK: GSDRC, University of Birmingham.

Macdonald, A., Davies, J., Calow, R. and Chilton, J. (2005). Developing Groundwater: A guide for rural water supply, Practical Action Publishing Ltd, Warwickshire.

Reed, W.E. (1951). Reconnaissance: Soil Survey of Liberia. Agriculture Information Bulletin, 66, p. 1-29.

Schlüter, T. (2008). Geological Atlas of Africa, 2nd ed., Springer, Berlin Heidelberg.

Seitz, J.F. (1974). Geology of the Voinjama Quadrangle, Liberia, U. S. Geological Survey.

Taylor, R. and Howard, K. (2000). A tectono-geomorphic model of the hydrogeology of deeply weathered crystalline rock: Evidence from
Uganda. Hydrogeology Journal, 8: 279-294.

Van Dongen, P. and Woodhouse, M. (1994). Finding groundwater: A project manager's guide to techniques and how to use them, UNDP-World bank water and sanitation program, Washington.

Williams, G.I. (2002). Liberia: the heart of darkness: accounts of Liberia's civil war and its destabilizing effects in West Africa. Trafford Publishing.

White, R.W. (1970). Reconnaissance mapping of weathered crystalline rocks in Liberia, Mining and Metallurgy Society Liberia Bulletin, 4, p. 96-102. Cited in: Beherent. J. C. and Wotorson C.S. (1974). Geophysical Surveys of Liberia with tectonic and geological interpretations, U. S. Geological Survey, Washington.

Wright, E.P. and Burgess, W.G. (1992). The hydrogeology of crystalline basement aquifers in Africa. Geological Society Special Publication, 66: 1-27.

Wurzel, P. (2001). Drilling boreholes for hand pumps, 1st ed., Swiss Center for Development Cooperation in Technology and Management, St. Gallen. 